\title{
Türk Kütüphaneciliğinin Kişisel, Kurumsal ve Entelektüel Bilgi Birikimini Derleme Çalışmaları ve Elektronik Erişim Olanakları
}

\author{
The Studies in Turkish Librarianship for the Collection of \\ Individual, Institutional and Intellectual Accumulation of \\ Knowledge and the Possibilities of Electronic Access
}

\section{Mehmet TOPLU*}

\begin{abstract}
Öz
Kişisel, kurumsal ve entelektüel bilgi birikimi, bir bilim ve/veya meslek dalının tanımlanmasında, gelişim koşullarının saptanmasında en önemli araçların başında gelmektedir. Bilginin yayımından erişimine kadar geçen sürecin her aşamasında yetkili ve sorumlu olan kütüphaneciler, aynı zamanda kendi kişisel, kurumsal ve entelektüel bilgi birikimine erişmeye olanak sağlayacak araç ve ortamları yaratmakla yükümlüdürler.

Türkiye'de bilginin erişiminde karşılaşılan birçok temel sorunun kütüphanecilik alanında da yaşandığı gözlenmektedir. Kütüphaneciler, kişisel, kurumsal ve entelektüel bilgi birikiminin erişimine olanak sağlayacak araç ve ortamları etkin bir biçimde yaratabilmiş değildir. 2006 yılında bu sorunlara çözüm üretebilmek amacıyla Üniversite ve Araştırma Kütüphanecileri Derneği (ÜNAK) öncülügünde bir proje başlatılmıştır. Bu proje ile, Türkiye'deki kütüphanecilik alanıyla ilgili kişisel, kurumsal ve entelektüel bilgi birikimine elektronik ortamda erişim hedeflenmiş ve bu amaçla 2006 yılında "Türkiye'de Kütüphanecilikte Kim Kimdir" adlı proje elektronik ortamda uygulamaya konulmuştur. 2007 yılından itibaren "Türkiye Bilgi Merkezleri Rehberi" yine elektronik ortamda hazırlanmaya başlanmıştır. Projenin üçüncü aşamasında; kütüphanecilik alanında üretilmiş olan raporlar, bildiriler, vb. elektronik ortamda erişilebilir hale getirilmeye çalışılacaktır.
\end{abstract}

Anahtar sözcükler: Kütüphaneciler, Kütüphaneler, Bilgi merkezleri, Rehberler-Türkiye, Türk kütüphaneciliği.

\footnotetext{
Dr.; Gazi Üniversitesi Mimarlık Mühendislik Fakültesi Kütüphanesi 06570 Maltepe Ankara
} (mtoplu@gazi.edu.tr). 


\begin{abstract}
The accumulation of individual, institutional and intellectual knowledge is the most basic and important instrument in the determination of the progress and conditions of any branch of science and/or profession. The librarians who have qualifications and responsibilities in every stage of the process extending from publication to the accession of knowledge, are at the same time responsible for providing necessary instruments and environments. In Turkey librarians started to create effective instruments and conditions necessary for the accession to the individual, institutional and intellectual accumulation of knowledge. A new project has been set up in 2006 under the leadership of University and Research Librarians' Association. The objective of this project is to provide accession to the individual, institutional and intellectual accumulation of knowledge in electronic form in the field of librarianship, and therefore, in the same year a new project called "Who is Who in Librarianship in Turkey" has come into being in electronic form. From 2007, onwards "The Directory of Information Centers in Turkey is being prepared in electronic form. In the third stage of the project, the reports, papers, etc. related to librarianship will be also available for accession in electronic form.
\end{abstract}

Keywords: Librarians, Libraries, Information centers, DirectoriesTurkey, Turkish librarianship.

\title{
Giriş
}

Bilimsel ya da mesleki bir alanı tanımlamak, gelişim düzeyini belirlemek, yaşamsal alanlara olan katkısını ortaya koyabilmek ve en önemlisi devletin ve/veya toplumsal kesimlerin bu alan/alanlara olan destek ve bakış açılarını ortaya koyabilmek için, her şeyden önce o mesleği icra eden kişi ve kurumların niteliklerinin ayrıntılı bir biçimde irdelenmesi gerekmektedir. Ayrıca bir meslek alanında üretilmiş olan bilimsel çalışmaların, ulusal ve uluslararası ölçekte o mesleğe sağladığı katkı da üzerinde durulması gereken başka bir önemli noktadır.

Bir bilim dalı ya da mesleğin gelişiminin temel kıstası, o alanda faaliyet gösteren insan gücüdür. Eğitim düzeyi, mesleki alandaki politikaları belirleme ve uygulamada etkin olabilme çabaları, gelişmeleri yakından izleyip bunları uygulamaya aktarabilme becerisi ile mesleği ilgilendiren diğer alanlarla ilişki ve işbirliği kurabilme yeteneği insan gücünün niteliklerini belirleyen temel unsurlardır. Toplumsal ölçekte mesleğin ve/veya bilim dalının kazanmış olduğu statü ve değer, mesleki 
gelişimin daha fazla dinamizm kazanmasına olanak sağlarken, o mesleği tercih eden kişilerin niteliğini de değiştirmektedir. Aynı şekilde insan gücünün eğitimini sağlayan kurumlar da bu gelişmelerden anında etkilenmektedirler.

Bilimsel ve/veya mesleki bir alanın tanımlanmasına olanak sağlayan diğer bir unsur, o alanda faaliyet gösteren kurum ve kuruluşlardır. Kurum ve kuruluşların ulusal ve uluslararası ölçekte gelişmişlik düzeyleri, faaliyet gösterdikleri alanlarda bireylere ve topluma sağladığı katkılar ile devlet ve toplumun bu alana desteği önemli birer göstergedir. Mesleki kurumların sağlıklı bir gelişim gösterebilmesinin temel koşulu, onlar tarafından üretilen ve/veya sunulan hizmetlerin bireyler ve toplum tarafından talep edilmesi ile doğru orantılıdır

Bir bilim ve meslek dalının gelişim dinamiklerinin izlenmesi ve tanımlanmasını sağlayan en önemli faktör hiç kuşkusuz, o alanda üretilmiş bilim ve düşün ürünleri ile onların nitelikleridir. Üretilen bilginin, ulusal ve uluslararası ölçekte niteliği, mesleki sorunları toplumsal bağlamda tanımlama ve bunlara yönelik çözüm üretebilme katkısı gibi pek çok faktör bu alanın tanımlanmasında önemli işleve sahiptir. Ayrıca bir bilim ve/veya meslek dalının gelişimi, üretilen bilginin niteliği ile de doğru orantılıdır.

\section{Kişisel, Kurumsal ve Entelektüel Bilgi Birikimine Erişim Yöntemleri ve Araçları}

Bir bilim ve/veya meslek dalının kişisel, kurumsal ve entelektüel varlığının anlam ifade edebilmesi ve toplumsal düzeyde işlevsellik kazanabilmesi için, onunla ilgili bilgilere erişim olanağını sağlayacak koşulların, araçların ve yöntemlerin geliştirilmesi gerekmektedir. Bu araç ve yöntemler, hem amaç ve hedefler, hem de üretildikleri ortam ve kullanıma sunuluş biçimleri açısından önemli değişiklikler gösterebilmektedir. Kişisel, kurumsal ve entelektüel bilginin içeriği ve niteliği, doğası gereği bazı farklıııkları da beraberinde getirmektedir.

Bilginin yayımında daha çok basılı araçların kullanıldığı dönemlerde, anılan bilgi türlerinin derlenip belirli bir formatta kamuoyu tarafından ulaşılabilir hale getirilmesi sürecinde güncellik, erişilebilirlik ve yaygınlaştırılmasında bazı temel sorunlar her zaman var olmuştur. Özellikle kişisel ve kurumsal bilgilerin her açıdan sürekli değişebilir bir nitelik taşıması, basılı olarak hazırlanmış bilgi kaynaklarının kullanıma sunulduğu andan itibaren güncelliğini yitirmesi sorununu da beraberinde 
getirmiştir. Bununla birlikte, özellikle gri yayınlar olarak adlandırılan, belirli bir kurum ya da çalışma grubu tarafından üretilen, erişimi sınırlı olan, fakat dönemi içerisinde bu alanlardaki politika ve uygulamaların belirlenmesinde önemli rol oynayan birçok rapor vb. çalışma da, sınırlı erişiminden dolayı, kamuoyu tarafından yeterince değerlendirilememiştir.

Bilişim teknolojisinin gelişimi, buna bağlı olarak bilgi kaynaklarının yayımı ve erişiminde etkin bir biçimde kullanılmaya başlanması, gerek bilgi merkezleri, gerekse bilgi hizmetleri için birçok yeni olanak yaratmıştır. Elektronik yayıncılık, basılı kaynakları ikinci plana iterken, bilgiye erişimde başat rol oynayan bilgi merkezleri, eski etkinliğini kaybetmektedir. Bunun sonucu olarak, bilgi merkezi odaklı politikalar, bilginin yayımı ve erişimindeki gelişmeler çerçevesinde değişime uğramış, bilişim teknolojisinin var olduğu her alan, birer bilgi erişim noktası haline gelmeye başlamıştır. Bilişim teknolojisinin bilginin yayımı ve erişimindeki katkılarının yanında, onun düzenlenmesi aşamasında da katılımcı ve işbirliğine dayalı bir anlayışı da beraberinde getirmiştir. Özellikle kişisel ve kurumsal bilgilerin erişimine olanak sağlayan veri tabanları, bizzat kişi ve kurumların katılımları ve işbirliği ile oluşturulabilmektedir.

Kişisel bilgilerin erişimine olanak sağlayan ve bu amaçla hazırlanan bilgi erişim araçları, biyografiler, otobiyografiler ve "kim kimdir" türü kaynaklardır. Çok eski bir yazın türü olan biyografiler ve otobiyografiler toplumda önemli bir yere sahip kişilerin yaşam öykülerini sunarken (Wellek ve Warren, 1977, s. 75); "kim kimdir" türü kaynaklar ulusal ve/veya uluslararası ölçekte belirli bir meslek ya da bilim dalı göz önünde tutularak oluşturulmakta, bu eserlerde bilim, sanat, kültür, edebiyat, politika vb. alanlarda belirli bir başarı elde etmiş kişilere ait tanımlayıcı bilgilere yer verilmektedir. Bu kaynaklarda genel olarak kişilerin nüfus bilgileri, ailevi durumu, eğitimi, mesleki uygulamaları, bilimsel ve akademik çalışmaları gibi bilgiler yer almaktadır. Böylece aranan kişinin uzmanlık alanları, mesleki ve bilimsel başarıları, hatta toplumsal konumu belirlenebilmektedir.

$\mathrm{Bu}$ tür bilgi kaynaklarında yer alabilmek için, her ne kadar bilim, sanat, edebiyat, kültür, yönetim vb. alanlarda başarılı ve tanınmış olma gibi birtakım temel ölçütler bulunmasına karşın, bazı subjektif değerlendirmelerle de karşı karşıya kalınabilmektedir. Örneğin bilim adamı tanımı yapılırken üniversitede çalışan herkes bu kapsamda mı değerlendirilecektir; edebiyat alanında bir ya da iki eseri olmak, "kim kimdir"de yer almak için yeterli midir, gibi pek çok soru akla gelmektedir. 
Bilim, edebiyat, sanat vb. alanlarda önemli gelişmeler kaydetmiş ve tanınmış kişiler yetiştirmiş olan ülkelerde "kim kimdir"de yer alabilmek için uygulanacak ölçütler daha seçici olabilmektedir. Buna karşın yeterince düşün ve sanat eserine sahip olmayan ve/veya bunları üretecek bireyin yetişmediği ülkelerde bu kaynaklarda yer alabilmek için uygulanacak değerlendirmeler daha esnek bir niteliğe sahiptir. "Kim kimdir" türü çalışmaların iki temel amacı vardır: Birincisi kişiyi ulusal hatta uluslararası ölçekte tanıtmak, ikincisi de kişiyi erişilebilir kılmaktır. Nitekim uluslararası ölçekte bu kaynakların hazırlanması yönünde önemli çabaların olduğu gözlenmektedir. Örneğin ilki 1935 yılında çıkan The International Who is Who'nun (2003) günümüze kadar 67 yeni basımı gerçekleştirilmiştir. Google'da İngilizce "who is who" başlığı ile yapılan taramada 1.590 .000 .000 kayda erişilmesi ${ }^{1}$, bu alandaki çalışmaların hangi boyuta ulaştığını göstermesi açısından son derece önemlidir.

Son dönemlerde özellikle bilişim teknolojilerinin gelişimi ile birlikte, bireylerin ya çalıştığı kurumlarca ya da kendilerinin bireysel olarak tasarladıkları web sitelerinde öz geçmişleri bulunmaktır. Bu tür sayfalar genellikle daha önceden belirlenmiş standart bir formatta hazırlanmadığından, farklı düzeylerde bilgiler içerebilmektedir. Ayrıca bu tür web sitelerinin dağınık yapısından dolayı, kişisel ve kurumsal bilgiler için sağlıklı bir erişim ortamı henüz oluşturulabilmiş değildir.

Bir bilim ya da meslek dalının tanınmasına, ,kataloglar, kılavuzlar ve benzeri bilgi kaynakları da katkı sağlar. Bunlar hazırlanış amaçlarına ve işlevlerine göre farklı türde ve içerikte olabilmektedir. Örneğin bazıları bir ülkenin ve/veya bölgenin turistik, tarihi ve doğal yörelerin tanıtımını amaçlarken (Akşit, 2002), bazıları da belirli bir alanda faaliyet gösteren kurum ve kuruluşların ürünlerini ve özelliklerini tanıtmaktadırlar (Yapı Kataloğu, 2006). Bazı rehberlerin içeriğinde ise, kurum ve kuruluşların kuruluş amaçları, üyelik bilgileri ve faaliyet gösterdikleri alanlar yer almaktadır (Akgün,1999). Bu tür rehber ve kılavuzlar bilimsel ve mesleki kurumların faaliyet alanlarını, sahip oldukları kaynakları tanıtmaları açılarından büyük önem taşımaktadır.

Gerek "kim kimdir", gerekse rehberler, kılavuzlar, kataloglar vb. türde yayınlar doğrudan birinci el bilgi kaynakları olmamasına karşın, mesleki alanda işbirliğinin yaratılmasında, kişi ve kurumların

${ }^{1}$ Tarama 8.5.2007 tarihinde: "who is who" anahtar sözcügü ile:

http://www.google.com.tr/search?hl=tr\&q=who+is+who\&meta= adresinden yapılmıştır. 
tanıtılmasında çok işlevsel bir role sahiptir ve bilimsel çalışmalara da önemli veriler sağlamaktadır.

Bir bilim dalı ya da mesleğin tanımlanmasında işlevselliği olan diğer bir unsur, o alanda üretilmiş olan düşün ve sanat ürünleridir. Bunlar kitaplar, süreli yayınlar, patentler, standartlar, tezler gibi birçok değişik bilgi kaynağı halinde kamuoyuna sunulmaktadır. Ayrıca bu kaynakların duyurulması için, ulusal ve uluslararası, konu ve/veya genel amaçlı bibliyografik denetim aracları ve veri tabanları oluşturulmaktadır. Bir bilim ve/veya meslek dalında sorunlu alanların saptanması ve bunlara yönelik çözüm önerilerinin dile getirilmesi konusunda ne kadar çok araştırma yapılıyorsa, o bilim ya da meslek dalı aynı ölçüde kendi gelişim dinamiklerini yaratabiliyor demektir. Özellikle uygulama ağırlıklı meslek dallarında, bilim adamı ve araştırmacıların, uluslararası gelişmeler çerçevesinde, ülke koşullarını göz önüne alarak, ulusal sorunlara çözüm getirebilme düzeyleri, o alandaki bilgi üretebilme kapasitelerinin belirlenmesi açısından son derece önemlidir. Bilim adamı ve araştırmacılar, mesleki gelişmelere sadece uluslararası ölçekte yaklaşıp bu gelişmeleri kendi ülkelerine uygulamakla mı yetinmektedir, yoksa yine bu gelişmeleri göz önünde tutarak kendi ulusal yapılarını uluslararası düzeye çıkarma yönünde bir bakış açısına mı sahiptir? Eğer sadece uluslararası gelişmeler temel alınarak bir uygulama anlayışı geliştirilmeye çalışılıyorsa, aslında orada bilim ve meslek adına yeni bir şey üretilmiyor demektir. Buna karşın bilim ve meslek adamları uluslararası gelişmeler ölçeğinde ulusal yapılarını, uluslararası düzeye çıkarabilme başarısını gösterebiliyorsa ve bilgi birikimlerini evrensel düzeyde kullanıma sunabiliyorsa, ancak o zaman mesleki bir başarıdan söz edilebilir. Tabii burada tartışılması gereken bir başka önemli nokta, bilim ve meslek adamları dışında kamu kurum ve kuruluşları ile toplumsal kesimlerin tutumu ve davranışlarıdır. Kamu kurum ve kuruluşları başta olmak üzere, bütün toplumsal kesimler, ilgili meslek dallarına, sorunların çözümlenmesi konusunda ne kadar destek sağlayabilmektedir, gerekli insan gücünü, maddi kaynağı, araç ve donanımı temin etme konusunda ne kadar duyarlıdır? Bu soruların yanıtları, özellikle kamu kurum ve kuruluşları tarafından üretilen bilgibelgeler ve bunların uygulamaya yansıması ile doğru orantılıdır.

Bilim insanı, araştırmacı ve meslek elemanlarının çalışmaları değişik bilgi kaynakları aracılığı ile kamuoyuna duyurulabilmektedir. Bu yaklaşım özellikle bilim insanı ve araştırmacılar açısından da bir zorunluluk taşımaktadır. 
Buna karşın kurumlar tarafından üretilen, fakat kamuoyunda yeterince paylaşılmayan birçok bilgi ve belge üretildiği ortamın sınırlarını aşamamaktadır. Bundan dolayı geçmişin politika ve yaklaşımları, geleceğe yeterince aktarılmadığından dün ve bugün yeterince ve doğru bir biçimde tanımlanamamakta, böylece geleceğin bakış açısı oluşturulmamaktadır.

Bilginin yayımı ve kullanımında kâğıda dayalı yayın endüstrisinin yaygın olduğu ve elektronik yayıncılığın henüz etkin olamadığı dönemlerde üretilmiş birçok bilgi ve belgeye erişmek, özellikle gelişmekte olan ülkelerde büyük ölçüde tesadüflere bağlıdır.

\section{Kütüphanecilikte Kişisel, Kurumsal ve Entelektüel Bilgi Birikimine Erişim}

Genel anlamda yukarıda yapılan kişisel, kurumsal ve entelektüel bilginin erişimi yönündeki tanımlamalar ve yaklaşımlar kütüphanecilik mesleği açısından da büyük ölçüde geçerlidir. Ancak kütüphaneciliğin diğer bilim dalı ve mesleklerle olan yakın ilişkisinden dolayı, özellikle kişisel bilgilerin sunulacağı "kim kimdir" türü kaynaklarda yer alacak kişilerin seçim ölçütleri son derece önemlidir. Özellikle gelişmekte olan ülkelerde bilgi hizmetleri bir bilim ve meslek dalı olarak uzun bir geçmişe sahip değildir. Bundan dolayı kütüphaneciliğin uygulama düzeyinde, meslek dışından birçok kişi yetkili ve/veya konu uzmanı olarak etkin görev yapmakta ve mesleğe katkıda bulunabilmektedir. Bütün bunlar göz önünde tutulduğunda mesleki alanda hazırlanan "kim kimdir" gibi kaynaklarda yer alacak kişilerin seçimi özel bir dikkat gerektirmektedir. Doğal olarak ölçütler oluşturulurken mesleki uygulamalar, başarılar ve katkılar ile bilimsel çalışmaların önemi daha da artmaktadır.

Kütüphanecilik alanındaki kurumsal bilgilere erişimde kullanılan rehberler, kataloglar, kılavuzlar vb. yayınlar, diğer alanlardaki aynı tür kaynaklarla benzerlikler taşımalarına karşın, içerik açısından birtakım farklııkları da bünyesinde barındırmaktadır. Bu durum bilgi merkezlerinin sahip olduğu kaynakların ve sunduğu hizmetlerin niteliğinden kaynaklanmaktadır. Bilgi merkezlerinde kitaplar, süreli yayınlar, mikrofişler, görsel-işitsel materyaller ve son dönemlerde veri tabanları gibi çok farklı bilgi kaynağı yer almaktadır ve bunların niceliği ve niteliği sürekli değişebilmektedir. Örneğin basılı kaynakların etkin olduğu dönemlerde sahip olunan kitap, süreli yayın vb. sayısı, hazırlanan bilgi merkezleri rehberlerinde önemli bir ağırlığa sahipti. Elektronik 
yayıncılığın gelişimi ile birlikte bilgi merkezleri, abone oldukları veri tabanları sayesinde, kullanıcılarına sahip oldukları bilgi kaynaklarından daha fazlasını sunma olanağı kazanmışlardır. Yine elektronik yayıncılığın gelişimi sayesinde bilgi merkezleri arasındaki işbirliği daha da artırmıştır. Artık bilgi merkezlerinin güçlerinin tanımlanmasında, kendi sahip oldukları dermenin yanında, erişebildikleri veri tabanları, işbirliğine gidebildikleri diğer merkezler ve bunlara bağlı olarak kullanıcılarına sunabildikleri yeni hizmet türleri ön plana çıkmaktadır. Doğal olarak bu etkenlerin yarattığı değişim, bilgi merkezleri rehberlerinin kapsamını, içeriğini ve niteliğini de etkilemektedir. Bunun yanında elektronik yayıncılıkla birlikte bu rehberlerinin hazırlanması ve güncellenmesi daha kolay hale gelmiştir. Yöneticiler ve/veya yetkili kişiler düzenlenmiş formları elektronik ortamda çevrimiçi olarak doldurabilmektedir. Bu da bilgi merkezleri rehberlerinin daha katılımcı biçimde hazırlanmasına ve daha güncel bilgilere erişimi olanak sağlamaktadır. Bilişim teknolojisinin gelişimi sayesinde, bunları iyi kullanabilen bilgi merkezleri, tasarladıkları web sitelerinde kendilerince önemli buldukları güncel, kişisel ve kurumsal bilgilere yer vermektedirler. Ancak web sitelerinin adreslerinin herkes tarafından yeterince bilinmemesi ve bu sayfalarda verilen bilgilerin standart bir formda olmaması her zaman istenilen türde bilginin kolayca erişimine olanak sağlamamaktadır.

Kütüphanecilik alanında düşün ürünlerinin yayımı, depolanması ve erişimi için izlenen yol ve yöntemler diğer bilim ve/veya meslek dalları ile hemen hemen aynıdır. Diğer bilim dallarında olduğu gibi, kütüphanecilik alanındaki bilgiye erişimi olanaklı kılmak için uluslararası düzeyde Library and Information Science Abstracts (LISA) (1969-) gibi bibliyografik denetim araçları geliştirilmiştir. Basılı formda hazırlanarak yayın hayatına başlayan bu bibliyografik kaynak, bilişim teknolojisindeki gelişmelerden yararlanarak elektronik ortamda üretilmeye ve sunulmaya başlanmıştır. LISA, günümüzde, kütüphanecilik alanında, yaklaşık 68 ülkede yayınlanan 440 dergiyi dizinleyerek önemli bir işleve sahip olmakla birlikte, uluslararası düzeydeki bütün yayınları dizinleyememesinden dolayı, özellikle gelişmekte olan ülkelere ait bilgiye erişimde hâlâ sorunlar yaşanmaktadır. Bu da gelişmekte olan ülkelerin kütüphanecilerinin mesleki bakış açılarının uluslararası düzeyde yeterince yansıtılamamasına neden olmaktadır. Bir başka deyişle, gelişmiş ülkelerin bakış açıları dünya kütüphaneciliğini yönlendirmede başat rol oynamaya devam etmektedir. 
Bununla birlikte elektronik yayıncılığın sonucu olarak, International Federation of Library Association and Institutions-IFLA (2007) ve American Library Association-ALA (2007) gibi birçok mesleki örgüt, sahip oldukları bilgi kaynaklarını çevrimiçi olarak meslektaşlarının kullanımına sunabilmektedirler. Aynı şekilde birçok ticari yayıncılık kuruluşu yayınlarını elektronik ortamda hazırlayarak kullanıma sunmakta ve pazarlamaktadır.

\section{Türkiye'de Kişisel, Kurumsal ve Entelektüel Bilgi Birikimine Erişim}

Türkiye'de genel olarak entelektüel, sanatsal, bilimsel, edebi, teknolojik vb. hemen hemen her tür bilgi kaynağının erişiminde ciddi sorunlar mevcuttur. Herhangi bir alanda bilimsel çalışma yapan birinin araştırma yaptığı alandaki bilgileri elde etmesi çoğu zaman tesadüflere bağımlıdır. Hâlbuki aynı araştırmacı bağlı bulunduğu veya yararlandığı bilgi merkezleri aracılığı ile uluslararası bilgileri daha rahat bir şekilde elde edebilmektedir. Bir başka deyişle, Türkiye'deki bilgi merkezleri abone oldukları elektronik veri tabanları ya da basılı kaynaklar sayesinde, kullanıcılarına, uluslararası bilgileri sunmada fazla bir güçlükle karşılaşmamaktadır. Ancak aynı durumu, ulusal bilgi birikimine erişim konusunda söylemek pek olanaklı değildir. Bunun iki temel nedeni vardır: Birincisi ulusal bilgi birikimine erişimi sağlayacak araçların etkin bir biçimde yaratılaması, ikincisi de yaratılanların da etkinlik kazanamamış olmasıdır. Gerek ulusal, gerekse konu düzeyinde hazırlanan birçok bibliyografik denetim aracı, üretildiği ortam ve zamanla sınırlı kalmış, bunlar sürekli olarak güncellenerek bilim insanı ve araştırmacılar için yol gösterici kılavuz haline dönüştürülememiştir. Özellikle konu bazlı bibliyografik denetim araçları, büyük ölçüde basıı ortamlarda üretilmiş ve zaman içerisinde güncellenememiş olmaları nedeniyle kullanımları sınırlı ölçekte gerçekleşmiştir ve belirli bir zaman sonra işlevsiz hale gelmiştir (Akbulut,1985; Akünal,1970; Kent Araştırmaları Bibliyografyası, 2001; Türkiye Felsefe Yayınları Kaynakçası, Kitaplar-Makaleler, 1928-1999; 2000).

Ulusal ölçekli bibliyografik çalışmalar kapsamında, Türkiye'de neredeyse tek ve sürekli olma özelliğine sahip Türkiye Bibliyografyası ve Türkiye Makaleler Bibliyografyası, bu alanda "bibliyografik denetim araçları" olarak yeterince işlevsellik kazanamamıştır. ${ }^{2}$ Bununla birlikte

${ }^{2}$ Türkiye Bibliyografyası 1934 yılını kapsamak üzere 1935, Türkiye Makaleler Bibliyografyası da 1952 yılından itibaren ulusal ölçekli bibliyografyalar olarak hazırlanmaya başlamış olmalarına 
TÜBITAK/TÜRDOK tarafından özellikle ulusal ölçekli bilimsel ve teknik enformasyonun erişimini sağlamak amacıyla 1967 yılında Key to Turkish Science dizisi ile başlatılan ve Temel ve Uygulamalı Bilimler Aylık Makale Duyuru Bülteni (1974); Temel ve Uygulamalı Bilimler Tez Duyuru Bülteni (1977); Bilimsel ve Teknik Veritabanı (1980) ve İçindekiler Dergisi (1988) (Toplu, 1991; ss. 242-248) ile sürdürülen çalışmalar entelektüel anlamda Türkiye'de önemli çığır açmış olmalarına karşın; düzenli ve uzun süreli yayınlanamadığından dolayı uygulamada etkin bir başarı sağlayamamışlardır. TÜBITAK/TÜRDOK'un 1996 yılında YÖK Dokümantasyon Merkezi ile birleşimi sonucu oluşturulan ULAKBIM, uzun bir aradan sonra, bu çalışmaların bir ölçüde devamı niteliğinde, elektronik ortamda Tıp; Sosyal Bilimler; Tarım, Veteriner ve Biyoloji Bilimleri; Mühendislik ve Temel Bilimler; TÜBITAK Destekli Projeler Veri Tabanlarını hazırlamaya başlamıştır. Bu kaynaklar kendi ölçütlerine göre, ulusal ölçekli bütün yayınları henüz dizinleyememiş olsa da, bu alandaki boşluğu doldurma açısından önemli aşamalar kat etmiştir. Buna karşın Türkiye'de özellikle kurumlar tarafından üretilen ve gri yayınlar olarak adlandırılan belgelerin erişimi ise neredeyse olanaksız denecek kadar azdır.

Yayınlara erişim konusundaki bütün bu sorunların yanında, özellikle temel ve uygulamalı bilim alanları başta olmak üzere, Türk bilim insanları ve entelektüeller ulusal bilgi birikimini küçümsemekte, hatta bir ölçüde yok saymaktadır. Bu da ulusal bilgilere erişime olanak sağlayacak araçların yaratılmasında, alt yapı koşullarının oluşturulmasında, yeterli desteğin sağlanmasını ve politikaların oluşturulmasını olumsuz yönde etkilemektedir.

\footnotetext{
karşın, gerçek anlamda birer bibliyografik denetim aracı haline gelememişlerdir. . Bu yayınlar zamanında ve güncel olarak yayınlanamadığı gibi, Derleme Yasası'nın güncelliğini yitirmesinden ve buna bağlı olarak bütün yayınların toplanamamasından dolayı, Türkiye'de bu bibliyografyalar aracılığı ile bütün düşün ve sanat ürünlerini takip edebilme olanağı bulunmamaktadır. Ayrıca Millı Kütüphane katalogları Internet üzerinden çevrimiçi erişime açılmış olmalarına rağmen bunların etkin ve verimli olarak çalıştığını söylemek olanaklı değildir. Bununla birlikte Milli Kütüphane tarafından hazırlanmakta olan Türkiye Yazmaları Toplu Kataloğu (Haz. Dursun Kaya ...[ve diğerleri]; Ankara: Milli Kütüphane, 2004) bu alandaki boşluğu doldurma açısından son derece önemlidir. Milli Kütüphane'nin bibliyografik denetim açısından önem taşıyan diğer iki çalışması da Eski Harfli Türkçe Eserler Bibliyografyası (Arap, Ermeni ve Yunan Alfabeleriyle): 1584-1986; (Ankara: Nüvis Beşeri Araştırmalar ve Yayıncılık Ltd.;y.t.) ve Cumhuriyet Dönemi Makaleler Bibliyografyası: 19231999 (Ankara: Nüvis Beşeri Araştırmalar ve Yayıncılık Ltd.; y.t.) dir. Bibliyografik denetim açısından son derece önemli olan her iki çalışma, elektronik ortamda hazırlanmış ve cd-rom şeklinde kullanıma sunulmuş olmalarına rağmen, bunlara Milli Kütüphane web sayfasından erişilememesi son derece düşündürücüdür.
} 
Türkiye'de kişisel bilgilere ulaşım için yapılan çalışmaların son derece yetersiz olduğu gözlenmektedir. Birey ve grupların siyasal, kültürel, eğitimsel vb. yönden gelişimlerinin izlenmesinde, toplumsal yaşam içerisindeki etkinliklerinin tanımlanmasında önemli işlevi olan biyografik ve otobiyografik eserlerin, Türk yazın hayatında "edebi bir ürün" olarak yeterince etkinlik kazanamadığı görülmektedir. Batı'da yazıldığı ilk dönemlerden itibaren biyografinin yoğun ilgi gördüğünü dile getiren Aslan (İşlenmemiş cevher, 2006) Türkiye'de günümüzde bile biyografi çalışmalarının Batının bir hayli gerisinde kaldığını, türün teorisi ve tekniği konusunda bilgilerimizin yetersiz olduğunu, kaynak sıkıntısının bulunduğunu ve en önemlisi toplumda Osmanlı'dan miras kalan mahrumiyet hissinin ve kapalı toplum olmanın bu alandaki çalışmaları engellediğini dile getirmektedir. Aynı çalışmada Murat Belge (İşlenmemiş cevher, 2006); Türkiye'de biyografi yazarlarının; Batıda olduğu gibi bireyler ve aileleri hakkında mektuplar, otobiyografiler, günlükler gibi her zaman birinci elden kaynaklara erişemeyebileceğini, toplumda "hayat fani; kaydını tutmaya gerek yok" gibi bir anlayışın hakim olduğunu; tanınmış insanların kendilerini daima tehlikede hissettiklerini ve kendileri hakkında hiç bir kayıt tutmak istemediklerini belirtmektedir. Talat Halman (İşlenmemiş cevher, 2006) da biyografinin Türk yazınında en geri alanlardan biri olduğunu, bireysel kültürden uzak oluşumuzun; inceleme yöntemlerini bilmeyişimizin ve biyografilerin az satılmasından dolayı araştırmacıların konuya fazla zaman ayıramamasının bunda önemli derecede rol oynadığını belirtmektedir. Halman ayrıca en iyi Atatürk yaşam öykülerini bile Türklerin değil, Lord Kinross ve Andrew Mango adlı iki İngiliz yazarın yazdığını vurgulamaktadır (İşlenmemiş cevher, 2006).

Türk kadın tarihi konularında çalışmalar yürüten Çakır (2006), biyografi ve otobiyografi çalışmalarının birey ve grupların tanınmasındaki rolünü şu cümlelerle anlatmaktadır: "Biyografi ve otobiyografi incelemeleriyle adını duymadığımız kadınları duymaya başladık. Adını duyduğumuz ama belli bir resmi söylem içinde tanıdığımız kadınların farklı hikayeleri olduğunu öğrendik."

Türkiye'de özellikle edebiyat alanındaki yazarların yaşam öyküleri ve eserleri hakkında önemli çalışmaların yapıldığı görülmektedir (Aydın, 1995; Kurdakul, 1999; Sever, 1993; Timuroğlu, 1991; Ünlü, 1987; Türk ve Dünya Edebiyatında Şairler, Yazarlar Sözlüğü, 198?). Hiç kuşkusuz bu kaynaklar, edebi kişilerin ve eserlerinin tanıtılması konusunda önemli bir boşluğu doldurmaktadır. Ancak burada sorgulanması gereken temel nokta, bunların ne kadarının gerçek anlamda biyografi ve otobiyografi; 
ne kadarının da eğitim öğretimi desteklemek amacıyla hazırlanmış yardımcı kaynaklar olduğudur. Eğer sorunun yanıtı gerçek anlamda biyografi ve otobiyografi hazırlanması ise, işte o zaman bu alanda belirli bir gelişmeden söz edilebilmesi olanaklıdır.

Türkiye'de genel anlamda "kim kimdir" türü bilgi kaynağı ilk olarak 1985 yılında hazırlanmış ve kamuoyu ile paylaşılmıştır. (Günümüz Türkiyesi'nde "Kim Kimdir": "Kim Kimdir" 85/86, 1985-2002). Kaynağın ilk basımında, 6481 bilim, düşün, sanat ve yazın adamı, politikacı, yönetici, asker ve benzeri kişilere ait bilgiler bulunmaktadır. Eserin 2002 yılında yapılan 8. basımında ise, 17.000 biyografik künyenin yer aldığı görülmektedir (Günümüz Türkiyesi'nde "Kim Kimdir"; "Kim Kimdir" 2002). Bu kaynak 17 yılda 8 basım gerçekleştirerek içeriğindeki biyografik kimlik sayısını üç katına çıkartmış, belirli ölçüde Türkiye'nin bilimsel, entelektüel, sanatsal, edebi, idari, askeri nitelikli bilinen kişilerin toplumda tanınmasını ve eserlerine erişilebilmesine olanak sağlamıştır.

Türkiye'de diğer alanlarda olduğu gibi kurumlara ait bilgileri bulmak da ciddi sorunlarla karşılaşılabilmektedir. Hazırlanmış birkaç kaynak dışında (Sivil Toplum Kuruluşları Rehberi: Baş/ıca Kuruluşlar, 1996; Uluslararası Kuruluşlar Rehberi, 1999) kurum ve kuruluşların çalışmaları, etkinlik alanları, personel veya üye sayıları, kaynakları vb. bilgilerine erişim konusu hâlâ önemli bir sorundur. Bilişim teknolojisinin gelişimi ve yaygınlaşması sonucu, kurum ve kuruluşlar web sitelerini hazırlayarak kendileri hakkındaki birçok bilgiyi sunmakta iseler de, sorun tam olarak çözülebilmiş değildir. Bütün bunlar göz önünde tutulduğunda, Türkiye'de genel anlamda ulusal ölçekli bilgiye erişimin temel bir sorun olmaya devam ettiği görülmektedir.

\section{Türkiye'de Kütüphanecilik Alanında Kişisel, Kurumsal ve Entelektüel Bilgi Birikimine Erişim Olanakları}

Kütüphanecilik alanındaki bilgi erişimi, Türkiye'deki genel bilgi erişim sorunlarından soyutlamak olanaksızdır. Diğer bütün bilim ve meslek disiplinlerinde olduğu gibi, kütüphanecilik alanında da kişisel, kurumsal ve entelektüel bilgi birikimine erişim konusunda gerekli araçlar, ortamlar ve koşullar oluşturulabilmiş değildir. Her ne kadar Türk kütüphanecileri; bilginin üretiminden kullanımına kadar devam eden süreçte, temel sorumlu meslek mensupları olsalar da, üzerine düşen sorumluluğu yerine getirebilmeleri konusunda gerekli toplumsal, ekonomik, teknolojik, politik vb. desteği sağlayabildiklerini söylemek pek olanaklı değildir. 
Bunun sonucu olarak Türk kütüphaneciliği kendi alanında gerek kuramsal gerekse uygulama düzeyinde mesleki gelişim dinamiklerini yeterince yaratabilmiş değildir. Bir başka deyişle, kütüphanecilik mesleğini icra eden kişi, kurum ve kuruluşlar mesleki uygulamalarda kendi irade ve katkılarını yansıtabilen bir başarıyı yeterince gösterebilmiş değildirler.

Kütüphanecilik alanındaki tanınmış kişilere ait bilgilere ulaşmak için çıkarılan birkaç anı kitabında yer alan biyografik bilgiler -örneğin, Prof. Dr. Osman Ersoy'a Armağan (1990); Nail Bayraktar'a Armağan (2004)ve Türk Kütüphaneciler Derneği Bülteni'nde ${ }^{3}$ yer alan tanıtıcı yazılar ile web sayfalarında yer alan özgeçmişler dışında bütüncül bir çalışma bulunmamaktadır. 1995 yılında Kahramanmaraş Sütçü İmam Üniversitesi Merkez Kütüphanesi web sitesinde Mehmet Bilmen tarafından "Kütüphaneciler kim kimdir" adlı çalışma, kütüphanecilere ait kişisel web sayfalarının adres bağlantılarını veren bir liste şeklinde başlatılmış, 1999'da bu listedeki bilgilere kütüphanecilerin kişisel web sayfaları, çalıştığı kütüphaneler ile ICQ ve/veya e-posta adresleri gibi iletişim bilgileri de eklenerek yayınlanmaya başlamıştır (Kütüphaneciler "Kim Kimdir", 2006). Bireysel çaba ile sürdürülen bu çalışma, kişisel bilgilerin toplanmasında belirli bir aşamaya gelmiş olmasına rağmen, kurumsal ve bütüncül bir yaklaşım olma özelliğine kavuşamamıştır.

Türkiye'de bilgi merkezleri alanında kurumsal düzeydeki bilgilere erişim konusunda iki temel çalışmanın yapıldığı görülmektedir. Bunlar Türkiye Kütüphaneleri ve Diğer Bilgi Merkezleri (1989) ile Türkiye Bilgi Merkezleri Rehberi $(1992 ; 1994 ; 1998)$ dir. Kültür Bakanlığı tarafından 1989 yılında Kültür Bakanlığı Kütüphaneler ve Yayımlar Genel Müdürlüğü tarafından hazırlanıp yayınlanan Rehber, Türkiye'deki bütün

\footnotetext{
${ }^{3}$ Türk Kütüphaneciler Derneği Bülteni yayın hayatına başladığı dönemde (1952-1955, c.1-4) Adnan Ötüken, Aziz Berker, Muzaffer Gökman gibi Türk kütüphaneciliğinin gelişimine önemli katkılar sağlamış kişilerin tanıtılmasını sağlamak amacıyla "Türk kütüphaneciliğine hizmet edenler" başlığı altında çalışmalar yürütmüştür. Adnan Ötüken'in yaşamına yönelik olarak Milli Kütüphane ve Adnan Ötüken (1972) (Ankara: Milli Kütüphane) adlı bir çalışma yapılmış ve bu daha sonra Türk Kütüphaneciler Derneği Bülteni'nin 21 (2) 1972 sayısının 65-74. sayfaları arasında Adnan Ötüken'in biyografisi başlığı ile özet olarak yayınlanmıştır. Türk Kütüphaneciler Derneği 1995 yılında Türk kütüphaneciliğine katkıda bulunanlara üstün hizmet ödülleri vermiş ve bu amaçla hazırladığı dokümanda (Türk Kütüphaneciler Derneği 1995 üstün hizmet ödülleri (1995) /Haz. Handan Pancarcı. Ankara: TKD.) ödül verdiği kişilerin biyografilerine yer vermiştir. Bununla birlikte Osman Ersoy'un yaşamının irdelendiği "Bilgi evinin çınarı: Kütüphanecilik alanının ilk profesörü/Konuşanlar: Hasan S. Keseroğlu, Şenol Armağan, Erkan Keser; teknik destek ve donanım Reşat Kölemenoğlu.1.bs. Ankara:Türk Kütüphaneciler Derneği, 2005. adlı eser de son dönemlerde bu konuda yapılan çalışmalara örnek gösterilebilir.
} 
bilgi merkezlerini kapsayacak biçimde hazırlanmış olmasından dolayı, bu alandaki en kapsamlı çalışmadır. Yine Kültür Bakanlığı tarafından 1993 yılında sadece halk kütüphanelerine yönelik olarak Halk Kütüphaneleri (Rehber)'i (1993) yayınlanmıştır. TÜBiTAK'ın ilki 1992 yılında yayınlanan, 1994 ve 1998 yıllarında yeniden gözden geçirilen rehberler ise üniversite ve araştırma kütüphanelerini kapsamaktadır. Gerek Kültür Bakanlığı'nın gerekse TÜBITAK'ın çalışmaları, hazırladıkları dönemlerde bu alanda gözlenen önemli bir boşluğu doldurmuşlar, ancak güncellenemediğinden belirli bir süre sonra işlevsiz kalmışlardır. Bununla birlikte bilgi merkezleri hazırlamış oldukları web sitelerinde, kendilerine yönelik tanıtıcı bilgilere yer vermektedirler. Kütüphanelerin web sitelerinde yer alan tanıtıcı bilgiler, bütüncül bir yaklaşım ve değerlendirmeye olanak sağlayacak bir yapıdan uzak olduğu gibi, bazı kütüphaneler de henüz web sitelerini hazırlayabilmiş değildir. Nitekim yapılan bir çalışmada (AI, 2000, ss. 321-322) üniversite kütüphanelerine ait web sitelerinin önemli bir kısmının belirlenen ölçütlerin gerisinde kaldığı, hatta bazı sitelerde kütüphaneye ilişkin temel bilgilerin bile yer almadığı belirtilmektedir.

Kütüphanecilik alanındaki entelektüel bilginin erişiminde karşılaşılan sorunları Türkiye'de genel anlamda mevcut sorunlardan ayırmak olanağı pek olmasa da, çözüm açısından en azından basılı kaynakların üretilmesi yönünde önemli adımların atıldığı görülmektedir. Muzaffer Gökman (1964) tarafından hazırlanan bibliyografya, Türkiye'de kütüphanecilik alanındaki entelektüel bilgiye erişimi sağlama yönündeki ilk çalışmalardan biridir. Uzun yıllar Türkiye'de kütüphanecilik alanında tek mesleki dergi olan Türk Kütüphaneciler Derneği Bülteni/Türk Kütüphaneciliği'ndeki makalelerin dizini bir grup çalışması ile oluşturulmuştur (Dizin: Türk Kütüphaneciler Derneği Bülteni/Türk Kütüphaneciliği (1952-1992), 1993; Dizin: Türk Kütüphaneciliği (19932000), (2001). Aynı şekilde kütüphanecilik alanında yapılan sempozyum ve panellerde sunulan bildirilerin bibliyografik denetimini sağlayan başka bir çalışmanın da yapıldığı görülmektedir (Anahtar: Kütüphanecilik, Arşivcilik ve Dokümantasyon-Enformasyon Alanlarında Yayınlanan Toplantı, Anı, Armağan ve Derleme Kitaplar Dizin: 2005). Kütüphanecilik, arşiv, dokümantasyon ve enformasyon alanında Türkiye'de yayımlanmış 56 sempozyum, anı, derleme ve armağan kitabını dizinleyen eser, önemli bir boşluğu doldurma niteliğine sahiptir. Milli Kütüphane tarafından hazırlanan Türkiye Bibliyografyası ve Türkiye Makaleler Bibliyografyası ile TÜBITAK/ULAKBİM'in hazırladığı Sosyal 
Bilimler Veri Tabanı birlikte ele alındığında, kütüphanecilik alanındaki bilgilere erişimde önemli aşamaların kat edildiği söylenebilir. Ancak bu kaynaklar bile güncel bilgiye elektronik ortamda erişim için yetersiz kalmakta, özellikle kurum ve kuruluşlar tarafından üretilmiş pek çok bilimsel ve teknik rapora ve bunların bibliyografik bilgilerine erişimini hâlâ olanaklı kılmamaktadırlar.

Bununla birlikte kütüphanecilik alanındaki mesleki örgütlerin, bilimsel yayınlarını elektronik ortamda meslektaşlarının kullanımına sunmaya çalıştığı görülmektedir. Türk Kütüphaneciler Derneği 1952 yılından beri yayımlamakta olduğu Türk Kütüphaneciler Derneği Bülteni/Türk Kütüphaneciliği (2007) dergilerinin bütün sayıları tam metin olarak elektronik ortamda erişime açmıştır. Yine aynı şekilde ÜNAK'ın Bilgi Dünyası (2007) ve Türk Arşivciler Derneği'nin Arşiv Dünyası (2007) dergilerine de elektronik ortamda tam metin olarak erişilebilmektedir.

\section{Yeni Bir Proje Kapsamında Geleceğe Yönelik Çalışmalar ve Hedefler}

Kütüphanecilik alanındaki kişisel, kurumsal ve entelektüel bilgiye erişim sorunlarının çözümü için 2006 yılından itibaren ÜNAK bünyesinde geniş kapsamlı bir çalışma yürütülmeye başlanmıştır. Bu kapsamda öncelikle kütüphanecilik bölümlerinden mezun olarak mesleğini icra edenler ile meslek eğitimini almamış olsalar bile, mesleğe uygulama ve eğitim düzeyinde önemli katkılar sağlamış kişilere ait bilgiileri kamuoyuna duyurabilmek amacıyla Türk Kütüphaneciliğinde "Kim Kimdir başlığıyla ÜNAK (2006) web sitesinde elektronik ortamdan verilerin girildiği ve arandığı bir veri tabanı hazırlanmıştır. İçerik belirlenirken uluslararası ölçekteki "kim kimdir" türü çalışmalar incelenmiş ve bireyin tanıtımına yönelik alanlar bu doğrultuda saptanmıştır. Mesleki tartışma listelerinde duyurulan veri tabanına veriler, katılımcı bir anlayışla kişilerin kendileri tarafından İnternet ortamından girilmeye başlanmıştır. İnternet erişimi olmayan, emekli olmuş veva ölmüş meslektaşlara ait bilgilerinin de proje kapsamında derlenerek veri tabanına eklenmesi planlanmıştır. Bu amaçla basılı veri formu hazırlanarak mesleki diğer dernek ve kurumlara gönderilmiş, ilgili isimler saptanmaya başlanmıştır. Bu Proje ile, Cumhuriyet dönemi boyunca Türk kütüphaneciliğine katkıda bulunmuş bütün kütüphanecilerin mesleki deneyimleri, çalışma alanları, mesleğe katkıları, ilgi alanları, ailevi durumları, sosyal ve ekonomik yapıları ortaya konabilecektir. Bir başka deyişle Türk kütüphanecisinin, onun bazında Türk kütüphaneciliğinin ulusal belleği ortaya konabilecektir. 
Projenin ikinci aşaması olan Türkiye Bilgi Merkezleri Rehberi (ÜNAK, 2007) de 2007 yılından itibaren yine elektronik ortamda hazırlanarak kamuoyuna duyurulmuş ve bilgi merkezi yöneticileri ve/veya yetkilileri tarafından bilgiler girilmeye başlanmıştır. ${ }^{4}$ Yılın belirli dönemlerinde güncellenecek olan bu rehber sayesinde, bilgi merkezleri hakkında güncel ve doğru bilgilere elektronik ortamda anında erişilebilecektir. Elektronik ortama sahip olmayan bilgi merkezlerinin verileri de basılı formlarla elde edilerek veri tabanına aktarılacaktır.

Projenin üçüncü aşamasında Türkiye'de kütüphanecilik, arşiv, dokümantasyon ve enformasyon alanında yayınlanmış bütün entelektüel ürünlerinin elektronik tam metinlerinin erişimi sağlanacaktır. Bu kapsamda öncelikle, elektronik ortamda erişimi olanaklı olan belgelere bağlantılar yapılacaktır. ikinci aşamada basılı/yazılı raporlar, bildiriler ve benzerleri elektronik ortama aktarılarak kullanıma sunulacaktır. Böylece kütüphanecilik alanında üretilmiş bütün bilimsel makaleler, bildiriler, raporlar hatta kitaplar elektronik ortamda erişilebilir hale gelecektir.

Projenin Yürütülmesinde Karşılaşılan ve/veya Karşılaşılabilecek Sorunlar

Bu kadar geniş kapsamlı projenin başarıya ulaşabilmesi için aşıması gereken birçok sorun mevcuttur. Bu sorunlar şu şekilde sıralanabilir:

Kişisel bilgilere erişim: Türk Kütüphaneciliğinde "Kim Kimdir" projesi mesleki çevrelere duyurulduğunda ve veri girişleri için veri tabanı kullanıma açıldığında ${ }^{5}$ yoğun bir ilgi ile karşılanmasına karşın, bazı meslek mensuplarının bu projeye belirli bir mesafeden yaklaştığı gözlenmektedir. Bir grup meslek mensubu iş yoğunluğu gibi nedenlerle veri tabanına henüz biyografik kimliklerini girmemiş olsalar da, bazı meslektaşların bu veri tabanında yer almak istemedikleri anlaşılmaktadır. Bu yaklaşımın temel nedeni, daha önce belirtilen ve genel anlamda Türk insanında mevcut olan, kişisel bilgilerin belirli yerlerden erişilebilecek olmasının kötü amaçlarla kullanılabileceği kaygısı etken olabilir.

Proje, bütün elektronik ortamlar, mektup vb. basılı kaynaklar aracılığı ile meslek mensubu herkese duyurulmaya çalışılmışsa da, kişisel ve kurumsal bilgilerin yetersizliği nedeniyle, bazı meslek mensuplarına hâlâ ulaşılamamıştır. Biyografik bilgilerin

\footnotetext{
${ }^{4}$ 9. 5.2007 tarihi itibari ile ilgili veri tabanında 48 bilgi merkezinin kayıtları yer almaktadır.

${ }^{5}$ 9. 5. 2007 tarihi göz önünde tutulduğunda veri tabanına biyografik kimliklerini giren meslek mensubu sayısı 475' dir.
} 
toplanmasında asıl sorun ise, emekli olmuş ya da ölmüş meslek mensuplarının saptanması sürecinde yaşanmaktadır. Bu kişilerin belirlenmesi, yaşam öykülerinin elde edilmesi hatta ailelerine ulaşılması daha uzun bir süreç alacaktır.

$>$ Kurumsal bilgilere erişim: Kişisel bilgilerin toplanmasında karşılaşılan sorunlar hemen hemen aynı ölçüde Bilgi Merkezleri Rehberi'nin hazırlanması esnasında da yaşanabilecektir. Bunun iki temel nedeni vardır: Birincisi bilgi merkezlerine böyle bir projenin varlığını bilgilendirmede karşılaşabilecek adres ve erişim bilgilerinin yetersizliğidir. Bu alanda daha önce yapılmış çalışmalar ve İnternet üzerinden iletişim olanakları, bilgi merkezlerinin belirlenmesinde önemli ölçüde katkı sağlamaktadır. Ancak, adres değişikliği, yeni bilgi merkezlerinin kurulması ve/veya var olanlardan bazılarının kapanması gibi etkenler bu alanda bazı sorunların yaşanmasına neden olmaktadır. İkincisi de bilgi merkezleri yöneticilerinin ve/veya yetkililerinin bu veri tabanını doldurmada isteksiz ve/veya duyarsız davranma intimalidir. Nitekim Türk Kütüphaneciliğinde "Kim Kimdir" adlı çalışmadan haberdar olan pek çok meslektaşın, halen kendi biyografik verilerini girmeleri konusunda göstermiş oldukları isteksizlik bunun bir göstergesidir.

Entelektüel bilgiye erişim: Kütüphanecilik alanında üretilmiş olan bütün entelektüel bilgilerin elektronik ortama aktarılarak erişiminin sağlanması aşaması ise daha karmaşıktır ve diğer meslek örgütleri ile kuruluşlarının işbirliğini gerektirmektedir. Her şeyden önce bütün entelektüel ürünler derlense ve bütün belgeler saptansa dahi, bunların elektronik ortama aktarılabilmesi ve erişiminin olanaklı hale getirilebilmesi için eserlerin telif haklarını ellerinde bulunduran kuruluşlardan ve yazarlarından izin alınması gerekmektedir. Doğal olarak bu da geniş katılımlı bir işbirliğini zorunlu kılmaktadır. Türk kütüphaneciliğinde etkin bir işbirliği ortamının kurulmasında bu zamana kadar karşılaşılan sorunlar göz önüne alındığında, bu konuda ciddi çabalara gereksinim olduğu kendiliğinden ortaya çıkmaktadır. Bu ortak çaba gösterilebildiği zaman, Türk kütüphaneciliği sadece bu alanda değil, her alanda kendi gelişim dinamiklerini yaratabilecek bir düzeye gelecektir. 


\section{Projenin Sonuçlandığında Elde Edilecek Başarılar}

Üç aşamalı bu projenin tamamlanması ve sürekliliğinin sağlanması ile birlikte gerek Türk kütüphaneciliği gerekse, diğer bilim ve/veya meslek dalları açısından önemli kazanımlar elde edilecektir. Bunlar şu şekilde sıralanabilir:

1. Türk kütüphaneciliğinin kişisel, kurumsal ve entelektüel bilgi birikiminin derlenerek kullanıma sunulabilme aşamasına gelindiğinde, meslekle ilgili tarihsel bilgi birikimi, çalışmalar, uygulamalar, düşünce yapısı, kişisel ve kurumsal kimlikler ortaya konabilecek, bir bakıma bu alandaki ulusal bellek gözler önüne serilebilecektir.

2. Bu tür bir çalışma Türkiye'de "ilk" olma özelliğini taşıyacağından diğer bilim ve/veya meslek gruplarına örnek olacak, bir bakıma diğer alanlardaki çalışmalar için yol gösterici ve teşvik edici bir nitelik taşıyacaktır.

3. Proje, Türk kütüphaneciliğindeki işbirliği anlayışını geliştirecek, hatta bu konuda yeni deneyimler sağlayacak, kişi ve kurumların diğer çalışmalarına temel dayanak noktası oluşturacaktır. Kişi ve kurumlar kendi çalışma alanlarındaki kişisel, kurumsal ve entelektüel kaynaklara kolayca erişebileceklerinden işbirliği yapabilecek ve/veya ortak projeler yürütebilecek kişileri kısa sürede saptama olanağı elde edeceklerdir.

4. Oluşturulacak üç veri tabanı özellikle akademik çalışmaları destekleyici bir nitelik taşıyacak, içeriğindeki kişisel ve kurumsal bilgiler yeni akademik araştırmalara veri sağlayacak ve araştırmalar için yeni fikirlerin ortaya çıkmasına yardımcı olabilecektir. Ayrıca entelektüel bilgiye erişim sayesinde mesleğin daha önce göz ardı edilen alanları saptanarak, bunlara yönelik yeni çalışmalar yürütülebilecektir.

5. Kişiler ve kurumlar arasındaki iletişim sorunları büyük ölçüde çözümlenmiş olacaktır. Bir başka deyişle kişi ve kurumlara yönelik bütün bilgi birikimlerine tek bir siteden erişilebilecektir.

6. Türkiye'de ilk kez bir meslek grubunun bilgi birikiminin büyük çoğunluğu elektronik olarak toplu halde erişilebilir hale gelecektir. Böylece kütüphaneciler, bilgi hizmetlerinde uluslararası alanda hakim olan elektronik bilgi erişim düzeyine en azından kendi meslekleri açısından yakalayabileceklerdir. 
7. Kişisel bilgilere erişim sayesinde birçok meslek üyesinin biyografik ve akademik deneyimleri görülebileceğinden, özellikle nitelikli bilgi çalışanı talebi olan kurumlar, istediği türdeki elemanları bu veri tabanı sayesinde bulabileceklerdir.

8. Türk kütüphanecisinin gücünü ortaya koyabilmesi açısından da son derece önemli olan Proje sayesinde Türk kütüphanecisi bulunduğu noktayı, güçlü yönlerini, eksikliklerini, olası fırsatları ve tehditleri görebilecek ve yapılması gerekenleri belirleyerek geleceğe yönelik hedefler ortaya koyabilecektir.

\section{Sonuç}

Bilgiye erişim, insanlığın tarihsel gelişimi süreci içerisinde her zaman önemli konulardan biri olmuştur. Her dönem, kendi gelişim koşullarına uygun bilgi erişim araçlarını, koşullarını, yol ve yöntemlerini oluşturmuştur. Bilgi üretimi ve birikimi artıkça bu alanındaki çabalar profesyonelleşmeye başlamış, farklılaşan bilginin niteliğine uygun olarak, bilgi erişimi kendi içerisinde dönüşüm geçirmiştir. Bilgi yayım ve iletişim araçları, simge ve işaretlerden söze, sözden yazıya, yazıdan basılı ortama ve son olarak elektronik ortama doğru sürekli bir değişim içerisindedir. Bilginin üretiminden kullanımına kadar geçen her dönemde yeni fırsatlar ve olanaklar ortaya çıkmıştır. Basılı bilgi iletişim araçları, tarihsel süreç içerisinde önemli ağırlığa sahip olurken, yirminci yüzyılın ikinci yarısından itibaren bilişim teknolojisinin gelişimi ve kullanımı ile birlikte yeni bilgi yayım ve erişim araçları ortaya çıkmıştır. İletişim araçları ile yayılan bilgi daha çok sözlü ve görsel bilgi iletiminin yerini alırken, elektronik yayıncılık basılı bilgi yayımı ve erişim alanını etkisi altına almış, bir bakıma onun geleceğini tehdit etmeye başlamıştır. Elektronik yayıncılık, bilginin erişimi ve yayımında sunduğu yeni fırsatlarla, bilginin erişiminden yayımına kadarki yapılanmayı toplumsal yaşamın her alanında yeniden şekillendirmiştir.,

Bilginin yayımı ve erişimi alanındaki bu gelişmeler, bir meslek ve bilim dalı olarak kütüphaneciliği doğrudan etkilemekte, hatta bir meslek olarak kütüphaneciliğin gelişiminde, politikaların ve kuralların oluşumunda başat rol oynamaktadır. Kütüphanecilik bölgesel, ulusal ve uluslararası ölçekte bilginin erişimi ve yayımı alanındaki araçların oluşumunu tanımlarken, aynı zamanda kendi kurumsal örgütlenmesini de gerçekleştirmiştir. Bu kurumsal yapılanma sayesinde kütüphanecilik, 
kendi mesleği ile ilgili kişisel, kurumsal ve entelektüel bilginin erişimi alanındaki araçların yaratılması konusunda önemli işlevler üstlenmiştir.

Türkiye'de genel anlamda kişisel, kurumsal ve entelektüel bilginin erişimi alanında karşılaşılan bütün sorunlar kütüphanecilik alanında da geçerlidir. Bir bakıma kütüphanecilik bilginin yayımı ve erişimi alanındaki işlevini yeterince yerine getirememekte, bu alanda belirleyici olamamaktadır. Türk toplumu ve onun yöneticileri, karar almada ve alınan kararları uygulamada, iş ve gündelik yaşamın sürdürülmesinde bilgiye göre hareket etme özelliğini yeterince geliştiremediğinden, bilginin üretiminden kullanımına kadar geçen süreç içerisinde yer alan kurum, kuruluş ve uygulamaları da etkin bir biçimde desteklememekte ve bu alanlardaki politikaları sağlıklı bir biçimde saptayamamaktadır. Bu durum, doğal olarak bilgiyi toplumsallaştıran ve erişilebilir kılan, kurum ve araçları yaratan kütüphanecilik mesleğinin gelişimini de olumsuz yönde etkilemekte, mesleğin kendi varlığını kabul ettirecek politikaları ve uygulamaları etkin biçimde ortaya koyamamasına neden olmaktadır.. Genel anlamda bilgi erişim sorunlarının çözümünde yetersiz kalan kütüphaneciler, kendi alanlarındaki bilgiye erişim konusunda gerçekleştirilen çalışmalarda da etkinlik gösterememektedirler.

Üç aşamalı olarak yürütülen bu proje tamamlandığı zaman, Türkiye'de ilk kez bir meslek grubu kişisel, kurumsal ve entelektüel bilgi birikimine elektronik biçimde erişme olanağı sağlayacak araçları ve ortamları yaratmış olacak ve diğer meslek gruplarına öncülük edecektir. Bir bakıma kütüphanecilik, "meslek olarak" hangi noktada bulunduğunu, eksiklerinin neler olduğunu, neleri yapıp neleri yapamadığını, donanım ve bilgi birikiminin mesleğini ilerletmede ne kadar yeterli olduğunu görebilecektir. Bu proje mesleki alandaki bilgi erişim sorunlarına ilk kez somut çözümler önermekte ve bunları uygulamaya koymaktadır. 


\section{Kaynakça}

Akbulut, B. (1985). Kooperatifçilik bibliyografyası. Ankara: Tarım, Orman ve Köyişleri Bakanlığı.

Akgun, U. (1999). Uluslararası kuruluşlar rehberi. Ankara: Özürlüler İdaresi Başkanlığı.

Aksit, İ. (2002). Ancient civilizations and treasures of Turkey. İstanbul: Akşit Kültür Turizm Sanat Ajansı.

Akünal, T ve K. Bayraktar.(1970). Türk hukuk bibliyografyası: 1963-1965. İstanbul: Sulhi Garan Matbaası.

Al, U. ve H. K. Bahşişoğlu (2000). Türkiye'deki üniversite kütüphanelerine ait web sitelerinin içerik açısından değerlendirilmesi, Bilgi Dünyası, 1(2), 307-329

ALA:The American Library Association. (2007). 25 Ocak 2007 tarihinde ALA web sitesinden erişildi: http://www.alastore.ala.org/.

Anahtar: Kütüphanecilik, arşivcilik ve dokümantasyon-Enformasyon alanlarında yayınlanan toplantı, anı, armağan ve derleme kitaplar dizin (2005). C. Polat ve H. Odabaş. (Yay. Haz.). Ankara: Alp yayınları.

Arşiv Dünyası. 25 Ocak 2007 tarihinde Türk Arşivciler Derneği web sitesinden erişildi: http://www.arsivder.org.tr/bulten.asp.

Aydın, M. (1995). Ne Yazıyor Bu Kadınlar: Osmanlıdan Günümüze Örnekleriyle Kadın Yazar ve Şairler. Ankara: İlke.

Bilgi Dünyası. (2000-). 25 Ocak 2007 tarinde ÜNAK web sitesinden erişildi: http://www.unak.org.tr/BilgiDunyasi/.

Bilgi evinin çınarı: Kütüphanecilik alanının ilk profesörü. (2005). H. S. Keseroğlu, Ş. Armağan ve E. Keser. (Konuşanlar). Ankara: Türk Kütüphaneciler Derneği.

Çakır, S. Kadın tarihi çalışmaları 2.25 Ocak 2007 tarihinde http://www.bianet.org/2006/05/01/78373.htm 19.10.2006 adresinden erişildi.

Dizin: Türk Kütüphaneciler Derneği Bülteni / Türk Kütüphaneciliği (19521992). (1993) O. Gürdal.... [ve diğerleri]. (Yay. Haz.). Ankara:Türk Kütüphaneciler Derneği.

Dizin: Türk Kütüphaneciliği (1993-2000). (2001). Oya Gürdal...[ve diğerleri]. (Yay. Haz.). Ankara:Türk Kütüphaneciler Derneği.

Gökman, M. (1964). Türk kütüphaneciliğin bibliyografyası: Bir deneme: Kütüphane Haftası (23-29 Kasım 1964). Ankara: TKD.

Günümüz Türkiyesi'nde Kim Kimdir = Who's Who in Turkey 2002: Büyük Biyografi Ansiklopedisi. (2002). İstanbul: Profesyonel Ltd.

Halk kütüphaneleri (Rehber). (1993). Ankara: Kültür Bakanlığı.

İçindekiler Dergisi. (1988-1991). Ankara: TÜBITAK/TÜRDOK. 
IFLA-The International Federation of Library Associations and Institutions. 25 Ocak 2007 tarihinde IFLA web sitesinden erişildi: http://www.ifla.org/ll/index.htm.

The International who's who- (2003). (67th ed.). London: Europa Publications.

İşlenmemiş Cevher. (2006). Milliyet Kitap Eki. (11 Ağustos 2006). 25 Ocak 2007 tarihinde http://213.243.28.16/2006/08/11/kitap/akit.html. adresinden erişildi.

Kent araştırmaları bibliyografyası. (2001). B. Aksel ve F. Öğretmen. (Yay. Haz.). İstanbul: Türkiye Ekonomik ve Toplumsal Tarih Vakfı.

Key to Turkish Science. (1967-1972). Ankara: TÜBITAK/TÜRDOK.

Kurdakul, Ş. (1999). Şairler ve yazarlar sözlüğü. İstanbul : İnkılâp Kitabevi.

Kütüphaneciler kim kimdir. 3 Kasım 2006 tarihinde Kahramanmaraş Sütçü İmam Üniversitesi Merkez Kütüphanesi web sitesinden erişildi: http://kutuphane.ksu.edu.tr/Liblibrarians.htm.

Library and Information Science Abstracts. (1969-). London: Library Association; Bethesda: CSA. http://www.csa.com/factsheets/lisa-setc.php adresinden erişildi.

Milli Kütüphane ve Adnan Ötüken. (1972). Ankara: Milli Kütüphane.

Nail Bayraktar’a armağan. (2004). İstanbul: Atatürk Kütüphane Müdürlüğü.

Prof. Dr. Osman Ersoy'a armağan. (1990). Ankara: Türk Kütüphaneciler Derneği.

Sever, M. (1993). Divan'dan günümüze Türk kadın şairleri antolojisi. İstanbul: Yön.

Sivil toplum kuruluşları rehberi: Başlıca kuruluşlar. (1996). İstanbul: Türkiye Ekonomik ve Toplumsal Tarih Vakfı Sivil Toplum Kuruluşları Bilgi Merkezi.

Temel ve Uygulamalı Bilimler Aylık Makale Duyuru Bülteni/Monthly Current Awareness Service on Pure and Applied Scientific Articles. (19741980). Ankara: TÜBITAK/TÜRDOK.

Temel ve Uygulamalı Bilimler Tez Duyuru Bülteni/ Pure and Applied Sciences Turkish Dissertation Index. (1977-1980). Ankara: TÜBITAK/TÜRDOK.

Timuroğlu, V. (1991). Yazınımızdan portreler. Ankara: Başak.

Türk Kütüphaneciler Derneği Bülteni/Türk Kütüphaneciliği. 25 Ocak 2007 tarihinde Türk Kütüphaneciler Derneği web sitesinden erişildi: http://www.kutuphaneci.org.tr/web/node.php?id=293.

Türk Kütüphaneciler Derneği 1995 Üstün Hizmet Ödülleri. (1995). H. Pancarcı (Haz.). Ankara: Türk Kütüphaneciler Derneği.

Türk ve dünya edebiyatında şairler, yazarlar sözlüğü. (198?). A. Dereli (Haz.). İstanbul: Salan Yayınları. 
Türkiye kütüphaneleri ve diğer bilgi merkezleri. (1989). Ankara: T.C. Kültür Bakanlığı. Kütüphaneler ve Yayımlar Genel Müdürlüğü.

Türkiye bilgi merkezleri rehberi. (1994). Ankara: TÜBiTAK Enformatik Daire Başkanlığı Enformasyon Hizmetleri Müdürlüğü.

Türkiye bilgi merkezleri rehberi 1997. (1998). Ankara: TÜBITAK Ulusal Akademik Ağ ve Bilgi Merkezi.

ÜNAK. (2006). Türk kütüphaneciliğinde "Kim Kimdir". (2006). M. Toplu (Ed.); K. Çömlekçi ve M. Boz (Haz.). 25 Ocak 2007 tarihinde ÜNAK web sitesinden erişildi: http://www.unak.org.tr/yeni/index.html.

ÜNAK. (2007). Türkiye bilgi merkezleri rehberi. (M. Toplu (Ed.) ve K. Çömlekçi (Haz.) 9 Mayıs 2007 tarihinde UNAK web sitesinden erişildi: http://www.unak.org.tr/bbm/index.html

Türkiye felsefe yayınları kaynakçası: Kitaplar-Makaleler, 1928-1999. (2000). Ö. F. Akyol ve S. Y. Öge (Haz.). Ankara:Türkiye Felsefe Kurumu.

Uluslararası kuruluşlar rehberi. (1999). Ankara: Özürlüler İdaresi Başkanlığı

Ünlü, M. ve Ö. Özcan. (1987). 20. Yüzyıl Türk edebiyatı. İstanbul: İnkılâp Kitabevi.

Wellek, R. ve A. Warren. (1977). Theory of literature. (3rd.ed.). San Diego: Harcourt Brace Jovanovich.

Yapı katalogu 2006-2007. (2006). İstanbul: Yapı Endüstri Merkezi. 